ISSN: 2146-3042

DOI: $10.25095 /$ mufad.875237

\title{
Teknoloji Odaklı Muhasebe Çalışmalarına Genel Bir Bakış: DergiPark Akademik Veri Tabanı ve Journal of Emerging Technologies Temelinde Sistematik Bir Literatür Taraması*
}

\author{
Ümmügülsüm ZOR**
} Tolga ALA***

\section{ÖZET}

Bu çalışma, Journal of Emerging Technologies in Accounting ve Dergi Park veri tabanina dayall sistematik bir literatür taraması yaparak muhasebe alaninda teknolojik yeniliklerin adaptasyonunu içeren çalı̧̧maların eğilimlerini ve öne çıkan anahtar kelimelerin hem İngilizce hem de Türkçe literatüre dayalı bir karşılaştırma sunmak suretiyle incelemeyi amaçlamıştır. Sistematik literatür taramasından elde edilen sonuçlara göre, incelenen çalışmalarda en çok kullanılan konuların başında teknolojik açıdan XBRL, yapay zeka, veri analitiği ve blok zinciri ile muhasebe açısından denetimin geldiği söylenebilir. Ayrıca, ilgili Türkçe literatürde yapılan çalışmaların sayısının İngilizce çalışmaların gerisinde kaldı̆̆g söylenebilir. Öte yandan sinırl sayıdaki Türkçe çalışmalar, konu, içerik ve kapsam bakımından İngilizce literatür ile uyumlu görünmektedir.

Anahtar Kelimeler: Muhasebe, Teknoloji, Muhasebe Literatürü.

JEL Sinıflandirması: M40, N70.

A Review of Technology Focused Accounting Studies: A Systematic Literature Review Based on DergiPark Academic Database and the Journal of Emerging Technologies and

\section{ABSTRACT}

This study aims to conduct a systematic literature review based on the Journal of Emerging Technologies in Accounting and Dergi Park database to see the trends and keywords of studies in the respective fields in both English and Turkish via providing a comparison. According to the systematic review, it might be said that the most used topics are XBRL, artificial intelligence, data analytics, and blockchain in the technological aspect and audit in the accounting aspect of the studies reviewed. The number of studies in Turkish lags the English studies in the respective field. The limited number of Turkish studies seems to be consistent with the English literature in terms of the topic, content, and scope.

Keywords: Accounting, Technology, Accounting Literature.

Jel Classification: M40, N70.

\footnotetext{
* Makale Gönderim Tarihi: 05.02.2021, Makale Kabul Tarihi: 19.06.2021 , Makale Türü: Nitel Araştırma

** Dr. Öğr. Üyesi, Altınbaş Üniversitesi, İşletme Fakültesi, ummugulsum.zor@altinbas.edu.tr, ORCID: 00000001-5590-8292.

*** Dr. Öğr. Üyesi, Erzincan Binali Yıldırım Üniversitesi, Meslek Yüksek Okulu, tala@erzincan.edu.tr,

ORCID:0000-0002-5879-9201.
} 


\section{GİRIŞ̧}

Muhasebe, teknolojik gelişimin en hızlı yansıma bulduğu alanlardan biridir (Kotb vd., 2019: 445). Öyle ki, işletme departmanları arasında bilgisayar teknolojilerine ilk geçişi sağlayan ve kullanan muhasebe departmanı olmuştur. Son yarım asırda tüm sektör ve iş alanları ile birlikte muhasebe mesleği de teknolojiye bağlı bir dönüşüm yaşamıştır. Bu dönüşüm süreci, yevmiye kayıtlarının kalem ve kâğıtla tutulduğu yılların çok hızlı bir şekilde geride birakılarak özet muhasebe bilgisinin bir gösterge panelinde (dashboard) birçok kullanıcıya görünür hale geldiği bir gelişim serüvenidir. Öte yandan bu yaşanan değişime bir şekilde ayak uyduramama durumu muhasebenin eğitim sürecinden söz gelimi mutfağından başlayarak operasyonel süreçlere ve nihai muhasebe raporlarına kadar geçen her aşamada teknoloji adaptasyonuna karşı bir direnç olduğu da görülmektedir (Qasim ve Kharbat, 2018: 107). Direnişin nedenleri arasında mevcut sistemden memnuniyet, kaynak yetersizliği ve değişime karşı yetersiz bilgi olduğu söylenebilir (Walley vd.,1994: 23). Teknoloji adaptasyonuna karşı gösterilen direncin en büyük nedenlerinden biri olarak muhasebenin hali hazırda teknik bir alt yapı gerektiren bir alan olması ile ilişkilidir. Teknoloji adaptasyonu günümüzde yalnızca bilgisayar kullanmayı bilmek ve belirli standartları olan muhasebe yazılımlarını kullanmaktan çok daha ileri düzeyde örneğin kodlama gibi mühendislik kökenli beceriler gerektirmektedir.

Günümüzde yapay zeka teknolojileri tüm sektörlerin işleyiş̧ biçimini önemli ölçüde değiştirmiş durumdadır. Yaşadığımız dijital çağda sektörden bağımsız dijital olarak üretilen bilgiye yapılan atıflar örneğin ilk iş zekası önerilerine kadar geri gidildiğinde (Luhn, 1958: 314) muhasebe artık büyük veri (big data) çağında sadece muhasebe bilgisi değil aynı zamanda teknolojik donanım da gerektiren bir alana dönüşmüştür (Moffitt ve Vasarhelyi, 2013: 1). Bilimin toplum için olduğundan yola çıkarak muhasebe literatürünün de bu değişimi yakalaması, mevcut gelişmeleri gerek teorik olarak açıklayabilmesi gerekse ampirik olarak derinlemesine incelemeler veyahut çeşitli dinamik ve faktörler arasındaki ilişkileri ortaya koyması beklenmektedir. Öte yandan yukarıda bahsi geçen direncin yalnızca iş yaşamında değil akademik olarak da yaşanıyor olması kuvvetle muhtemeldir. Zira muhasebe derslerinin müfredatları açısından da bir direncin mevcut oldu ve teknoloji adaptasyonunun henüz muhasebe müfredatında hak ettiği yeri alamadığı da yapılan çalışmalarda belirtilmektedir ( bkz. Sledgianowski vd., 2017: 81).

Mevcut literatürün yıllar içinde teknolojik değişime ve bu değişime duyulan ihtiyaca ne şekilde karşıllk verdiğinin anlaşılması ve literatürde giderilmesi gereken boşlukların belirlenmesi amacıyla, bu çalışmada iki aşamalı sistematik literatür taraması yapılması amaçlanmıştır. İlk aşamada teknoloji odaklı anahtar kelimeler seçilmiştir. Bu seçimde sistematik bir yöntem olarak frekans analizi kullanılmıştır. Teknoloji odaklı anahtar kelimeler ile konu edildikleri yayınlardaki muhasebe odaklı anahtar kelimeler sınıflandııılmıştır. Böylece teknoloji- muhasebe odaklı anahtar kelimeler çift taraflı olarak sınıflandırılmıştır. İkinci aşamada ise yapılan sınıflandırma ile elde edilen ve sistematik taramaya temel oluşturacak anahtar kelimelerin Türkçe karşılıkları ile Dergi Park veri tabanında sistematik bir tarama yapılmıştır. Böylece, Türkçe literatür ile İngilizce literatürün örtüşme dereceleri tespit edilmeye çalışılmıştır. 
Çalışma bulgularına göre Türkçe literatürde çok az sayıda çalışma bulunmasına karşın işlenen konular ve teorik/ampirik önermeler bakımından büyük ölçüde İngilizce literatürle örtüştüğü ve öne çıkan teknolojik yeniliklerle ilişkin kapsamlı bilgi sunulduğu görülmektedir.

Çalışmanın devamında ikinci bölümde sistematik literatür taramasında izlenen protokoller detaylıca aktarılmış böylece mevcut çalışmanın ilerleyen yıllarda tekrarının yapılması için bir yol haritası belirlenmiştir. Üçüncü bölümde sistematik olarak incelenen konular JETA ve Dergi Park veri tabanında listelendiği hali ile olarak sunulmuştur. Devamında, ilgili konuların çeşitli alanlara göre dağılımına yıllar itibari ile yer verilmiş ve muhasebenin diğer sosyal bilimlere kıyasla literatürde teknolojiye yönelik durumu tespit edilmeye çalışılmıştır. Daha sonra ise öne çıkan konu başlıklarına göre gerek JETA gerekse Dergi Park çalışmalarının kapsamlarına yer verilmiş ve gelecekte yapılacak çalışmalar için önerilerde bulunulmuştur.

\section{SISTEMATIK LITERATÜR TARAMASINDA İZLENEN PROTOKOLLER VE ÇIKTILARI}

$\mathrm{Bu}$ çalışmanın temel amacı Türkçe literatürün uluslararası literatüre ne ölçüde yaklaştığını ve/veya işlenen konuların teknoloji-muhasebe ilişkisi ekseninde ne derecede örtüştüğünün tespit edilmesidir. Bu nedenle ilk olarak anahtar kelimeler özelinde teknoloji ve muhasebe odaklı konulara ilişkin ifadelerin tespiti gerekmektedir.

\subsection{Anahtar Kelime Seçimi}

Muhasebe literatüründe teknoloji adaptasyonuna ilişkin anahtar kelimeleri yakalamak amacıyla öncelikle bu alanda yayın yapan bir referans akademik dergi incelenmiştir. Dünyadaki en prestijli muhasebe örgütlerinden birisi olan Amerikan Muhasebeciler Birliği'nin (American Accounting Association [AAA]) gelişen teknolojilerin ve yapay zeka uygulamalarının geniş bir skalada muhasebe sorunlarını çözmesine imkan sağlayacak şekilde geliştirilmesi, bunların desteklenmesi ve sunulması amacıyla ilk olarak 2004 yılında yayınladığı ve halen yayınlanmaya devam eden "Journal of Emerging Technologies in Accounting (JETA)" adlı akademik dergi referans olarak seçilmiştir. EBSCO veri tabanından JETA'da yayınlanan tüm akademik çalışmalar yıl, yazar, makale başlığı, anahtar kelimeler ve özet bölümleri elde edilecek şekilde derlenmiştir. 2014-2020 (dahil) yıllarında listelenen 194 yayından Editör Notları ve yayın çağrıları çıkartıldığında geriye 173 akademik çalışma kalmaktadır. Bunlardan bir bölümünde JETA'nın tamamen sistematik bir yapıya sahip olmaması sebebiyle anahtar kelimeler listelenmemiştir. İncelendiğinde bu tip yayınların daha ziyade örneğin atıf değerlendirmesi (örneğin; O'Leary, D.E., 2009: 1, 2010: 89, 2011: 1) gibi incelemeler olduğu görülmüştür. Geriye kalan toplam 165 çalışmada, birbirinden farklı yayınlarda tekrar eden anahtar kelimeler de dahil olmak üzere toplam 620 anahtar kelime kullanılmıştır. Anahtar kelimelerin listelendiği muhasebe konuları ve konu edilen anahtar kelimeler kategorize edilmiştir. Anahtar kelimelerde örneğin "data mining (veri madenciliği)" gibi kelime gruplarının geçmesi halinde bir grup oluşturulmuştur. Örneğin, "data mining", data analytics" gibi ifadelerin frekansının yüksek çıkması halinde bir üst grup olarak "data (veri)" kelimesi seçilmiştir. Benzer şekilde "management information system (yönetim bilgi sistemi)" veya "accounting information system (muhasebe bilgi sistemi)” ifadelerinde her iki grubu da temsil etmesi ve her iki gruptan çalışmayı da sistematik taramada listeleyebilmek 
için "bilgi sistemi” ifadesi kullanılmıştır. İlaveten incelenen çalışmalarda yer alan muhasebenin konusuna giren anahtar kelimeler için ayrıca bir listeleme yapılmıştır.

Frekanslarına göre teknoloji konulu anahtar kelimelerden en az iki kez kullanılmış olanlar aşağıda Tablo 1'de sunulmuştur.

Tablo 1. Teknoloji Konulu Anahtar Kelimeler ve Frekansları

\begin{tabular}{|l|l|l|}
\hline Anahtar Kelime & Türkçe Karşılığı (varsa) & Frekans \\
\hline technology & teknoloji & 20 \\
XBRL & XBRL & 17 \\
artificial intelligence & yapay zeka & 14 \\
data analytics & veri analitiği & 13 \\
blockchain & blockchain & 9 \\
sentiment/text mining & duygu analizi/ metin madenciliği & 9 \\
Big Data & büyük veri & 6 \\
neural networks & sinir ağları & 4 \\
content analysis & içerik analizi & 4 \\
expert system & uzman sistem & 4 \\
fuzzy logic & bulanık mantık & 3 \\
REA (Resources, Events, Agents) & REA & 3 \\
smart contracts & akıllı sözleşme & 3 \\
data mining & veri madenciliği & 2 \\
deep learning & derin öğrenme & 2 \\
open data & açık veri & 2 \\
process mining & süreç madenciliği & 2 \\
robotic & robotik & 2 \\
\hline
\end{tabular}

Tablo 2. Muhasebe Konulu Anahtar Kelimeler ve Frekansları

\begin{tabular}{|l|l|l|}
\hline Anahtar Kelime & Türkçe Karşılı̆̆ı (varsa) & Frekans \\
\hline audit & denetim & 63 \\
reporting & raporlama & 19 \\
ERP & ERP (kurumsal kaynak planlaması) & 14 \\
fraud & hile & 11 \\
internal control & iç kontrol & 11 \\
decision making & karar verme & 9 \\
information & bilgi & 9 \\
accounting education & muhasebe eğitimi & 7 \\
earning & gelir/kazanç & 7
\end{tabular}




\begin{tabular}{|l|l|l|} 
information system & bilgi sistemi & 7 \\
business process & iş süreçleri & 6 \\
accounting information system & risk yönetimi & 6 \\
management accounting & muhasebe bilgi sistemi & 4 \\
corporate governance & yönetim muhasebesi & 4 \\
\hline
\end{tabular}

\subsection{Dergi Park Sistematik Literatür Taraması}

Dergi Park veri tabanında yer alan gelişmiş arama seçenekleri çok sayıda kelime ve/veya kelime grubunun belirli disiplinler altında listelendiği oldukça kullanışlı bir arama motoru sunmaktadır. Bu sayede, yukarıda listelenen anahtar kelimelere ilişkin toplu bir tarama yapmak mümkün olmuştur. Türkiye'deki akademik dergilerde listelen çalışmalarda İngilizce özet ve anahtar kelimelerin de yer alıyor olması sayesinde tercüme sebebiyle karşılaş1labilecek hataların önüne geçilebilmektedir. Buna uygun olarak Dergi Park arama alanında "technology” OR “XBRL” OR “artificial intelligence” OR “data analytics” OR "blockchain" OR "sentiment” OR "text mining” OR "big data” OR "neural networks” OR "content analysis” OR "expert system" OR "fuzzy logic” OR "REA” OR "Resources, Events, Agents” OR “smart contracts” OR “data mining” OR “deep learning” OR “open data” OR "process mining” OR "robotic" şeklinde ifadeleri sistematik bir tarama yapılmıştır. Anahtar kelimelerin taranması sırasında tüm kelimeler ya da ifadeler arasında "OR (veya)" kelimesinin kullanılması ile listelenen anahtar kelimelerden her hangi birinin geçtiği tüm çalışmaların tek seferde listelenmesini sağlamaktadır.

İlgili ifadelerle yapılan aramada listelenen toplam 139.404 araştırma makalesinden $3.396^{1}$ tanesi muhasebenin de kapsamına girdiği işletme ana başlığı altında toplanmaktadır. Listelenen bu çalışmalar da ikinci adım da muhasebeye ilişkin terimler aranmıştır. İlgili terimlere ilaveten "muhasebe (accounting)" ve "finans* (finance*)" ifadeleri ile de arama yapılmıştır.

Yapılan aramalarda ilgili tüm çalışmaların tespit edilmesi için hem Türkçe hem de İngilizce terimler kullanılmıştır. İlgili terimlerin başlık veya anahtar kelimelerde geçmesi bir filtre olarak belirlenmiştir. Listelenen çalışmalardan ikinci aşamada muhasebe alanında toplam 31 çalışma listelenmiştir. 31 çalışmadan iki tanesi İngilizce olarak diğerleri ise Türkçe olarak yayınlanmıştır.

\section{METODOLOJÍ}

Çalışma verilerinin yapılandırılması, kısıtları ve analiz yöntemleri hakkındaki bilgilere bu bölümde yer verilmiştir.

\footnotetext{
${ }^{1}$ Son sorgu ekranı 22.01.2021 tarihinde alınmıştır ve sonuçlar bu tarihe göre sunulmuştur.
} 


\subsection{Veri Yapılandırması}

Elde edilen Türkçe sonuçlarda benzer anlamlar için farklı terimler kullanılması literatürde oldukça yaygındır. Bu nedenle sağlıklı bir analiz yapabilmek için ilk olarak anahtar kelime standardizasyonu yapılmıştır. Buna göre, Türkçe çalışmalardan elde edilen veri her bir anahtar kelime için sınıflandırmaya tabi tutulmuştur. Örneğin; "finansal rapor" ve finansal tablo" ifadeleri temelde aynı bilgiyi temsil ettiğinden tek bir grupta ele alınmıştır. Benzer şekilde "finansal raporlama hilesi" ve "hile denetimi" ifadelerinde örtüşen ifade "finansal rapor" ve ayrışan ifadeler de "hile" ve "denetim" olduğundan bu iki anahtar kelime grubu üç ifadeyi temsil edecek şekilde yeniden yapılandırılmıştır. Yine benzer şekilde bir çalışmada "çok kriterli karar verme" ve bir başka çalışmada bu ifadenin kısaltması olarak kullanılan "ÇKKV" geçiyorsa bunlar tek bir terim olarak yapılandırılmıştır.

\subsection{Analiz Yöntemi}

Çalışmanın amacına uygun olarak nitel içerik analizi ve nicel içerik analizi birlikte yapılmıştır. Anahtar kelime incelemesi için gerek İngilizce gerekse Türkçe anahtar kelimeler listelenmiş, ana başlıklar altında kategorize edilmiş ve yıllar bazında frekans analizi yapılmışıır.

Çalışmanın devamında ise nitel içerik incelemesi yapılması suretiyle incelenen literatürün en yaygın konular özelinde bulgularına ve JETA yayınları ile Türkçe yayınların karşıllaştırmasına yer verilmiştir.

\section{3. Çalışmanın Kısıtları}

JETA 2004 yılından itibaren yayınlanan akademik bir dergi olması sebebiyle bu yıldan önce muhasebe ve teknoloji alanında yapılan yayınlar çalışma kapsamı dışında kalmıştır. Öte yandan Türkçe literatürün ilgili alanda çok sınırlı olması doğru bir karşılaş̧ırma ve değerlendirme yapılabilmesi açısından dar bir kapsama ihtiyaç duyulmuştur ve tek konuya özgü akademik dergi özelinde inceleme yapılmıştır. Ayrıca JETA'da genel olarak günün koşullarında öne çıkan teknolojik başlıklara yönelik düzenli olarak araştırma çağrısı yapıldığı ve editör notları ile ilgili teknolojik konuların ön plana çıkarıldığı görülmektedir. Bu da alanda çalışan araştırmacıların hali hazırda bir gündeme uygun çalışmalar yapmasını kolaylaştırmaktadır. Öte yandan Türkçe dizinde bu anlamda spesifik bir dergi yer almadığından muhasebe araştırmacılarının böyle bir şansı bulunmamaktadır. Bu durum Türkçe dizin açısından bir dezavantaj olarak görülebilir ve ilgili alandaki spesifik çalışmaların neden az sayıda olduğuna dair bir ip ucu verebilir.

\section{ANALIZ BULGULARI}

Araştırmadan elde edilen verilerin analizleri sonucunda ulaşılan bulgulara ve bu bulguların ilişkilendirildiği literatüre yer verilmiştir.

\subsection{Yıllara Göre Çalış̧aların Dağılımları}

Yapılan literatür incelemesinin en çarpıcı sonucu Türkçe literatürde muhasebe alanında teknolojiye yönelik incelemelerin uluslararası çalışmalara kıyasla oldukça geç 
araştırılmaya başlanmasıdır. Nitekim JETA'nın muhasebe alanında teknoloji kullanımına odaklanmış bir dergi olarak kuruluşunun 2004 yılı olduğu düşünüldüğünde bu tip çalışmaların esasında çok daha öncesinde başladığı düşünüldüğünde yoğunlaşan çalışmalar neticesinde bu alanda akademik bir dergi fikrinin ortaya çıktığını söylemek yanlış olmayacaktır.

Dergi Park veri tabanında yapılan sistematik taramadan elde edilen 31 çalışmanın yıllara ve yayın çeşidine göre dağılımı aşağıdaki gibidir.

Grafik 1. Yıllara Göre Akademik Çalışma Türleri- Dergi Park

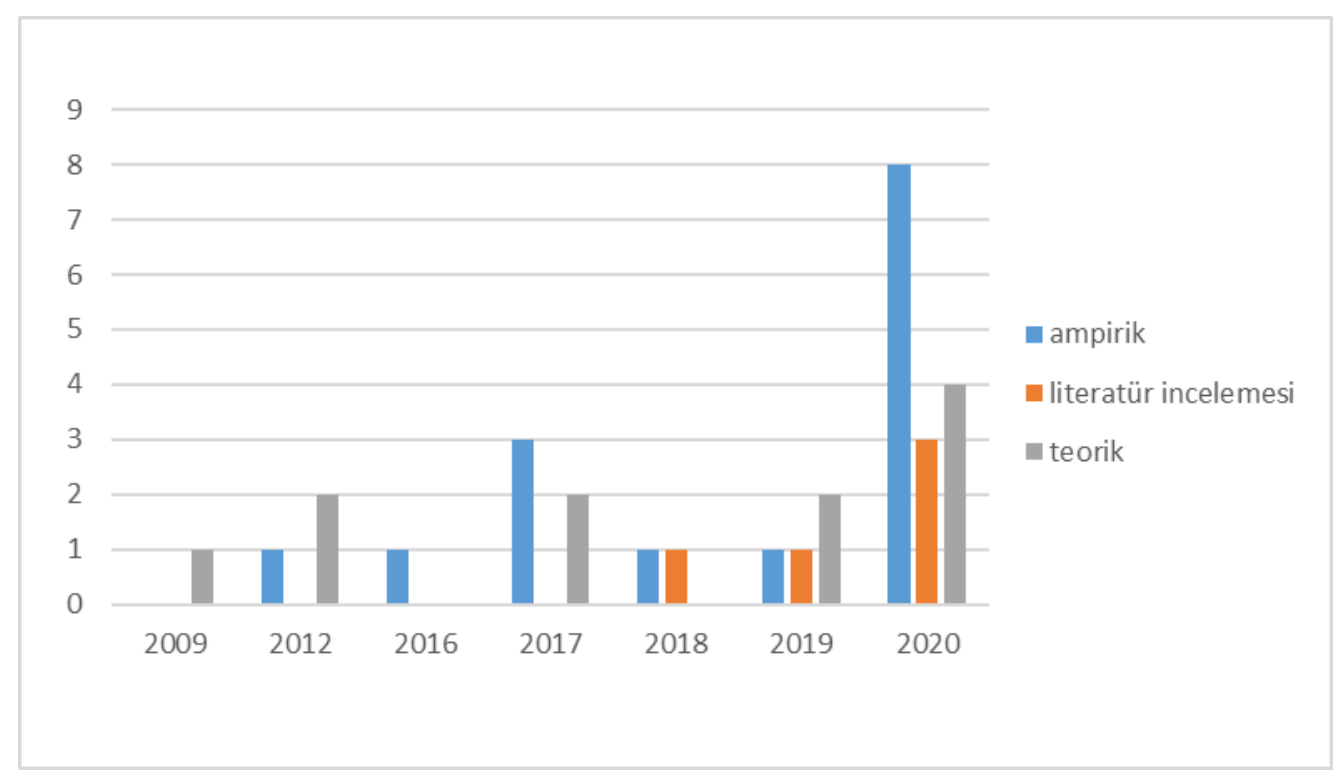

Görüldüğü gibi muhasebe alanında teknoloji kullanımına yönelik ilk çalışma 2009 yılında yapılımış teorik bir çalışmadır (Çıtak, 2009: 1). İzleyen yıllarda her ne kadar istikrarlı bir artış görülmese de 2020 yılında yapılan çalışmalardaki ciddi artış göze çarpmaktadır.

Çalışma türleri kadar incelenen konulara ilişkin bir analiz de sunmak gerekirse bu amaçla yıllar bazında işlenen konular gerek JETA gerekse Dergi Park veri tabanı için aşağıda bir arada sunulmuştur. 
Grafik 2. Y1llara Göre Teknoloji Anahtar KelimeleriJETA

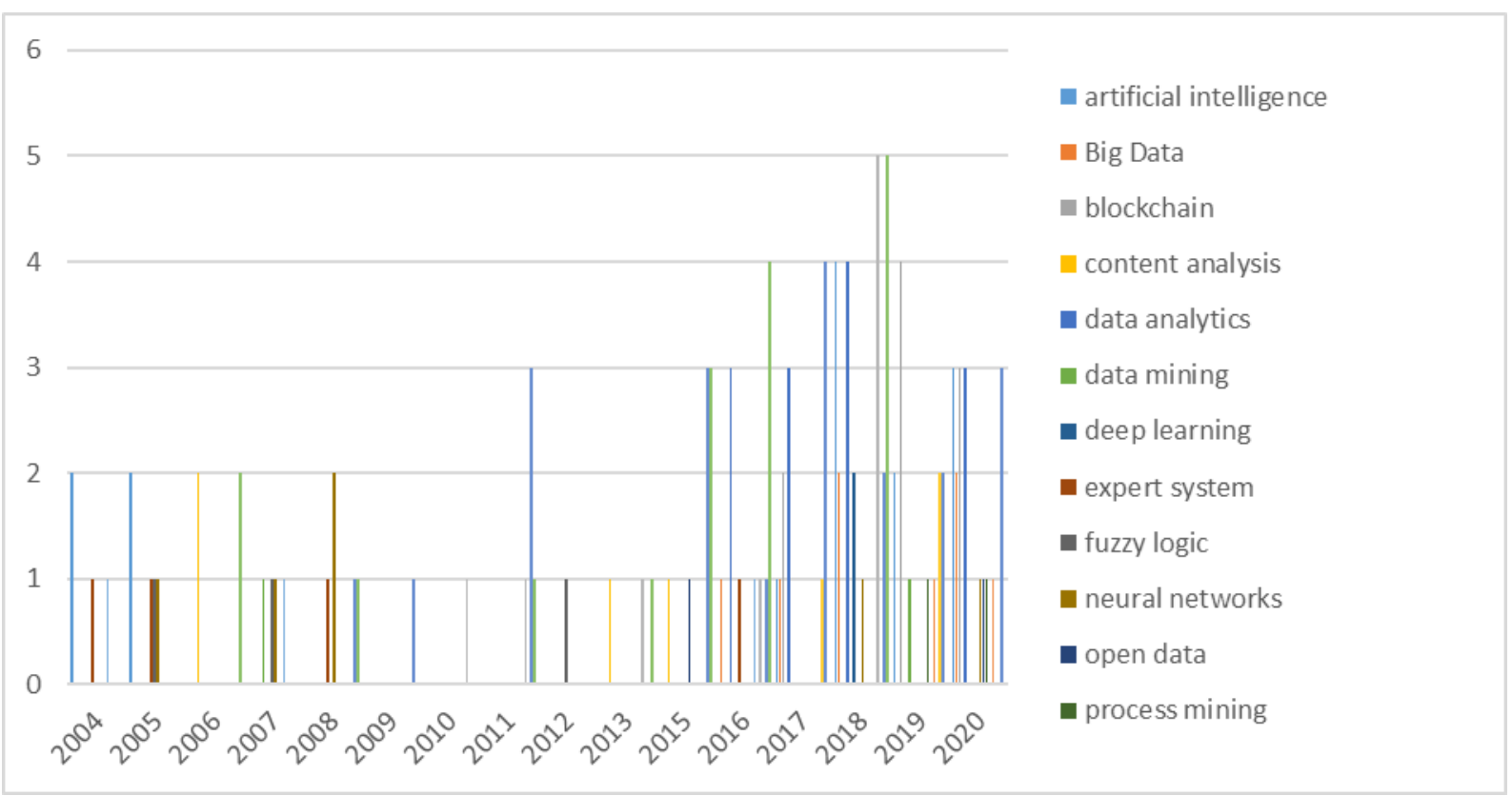

Grafik 3. Y1llara Göre Teknoloji Anahtar Kelimeleri- Dergi Park

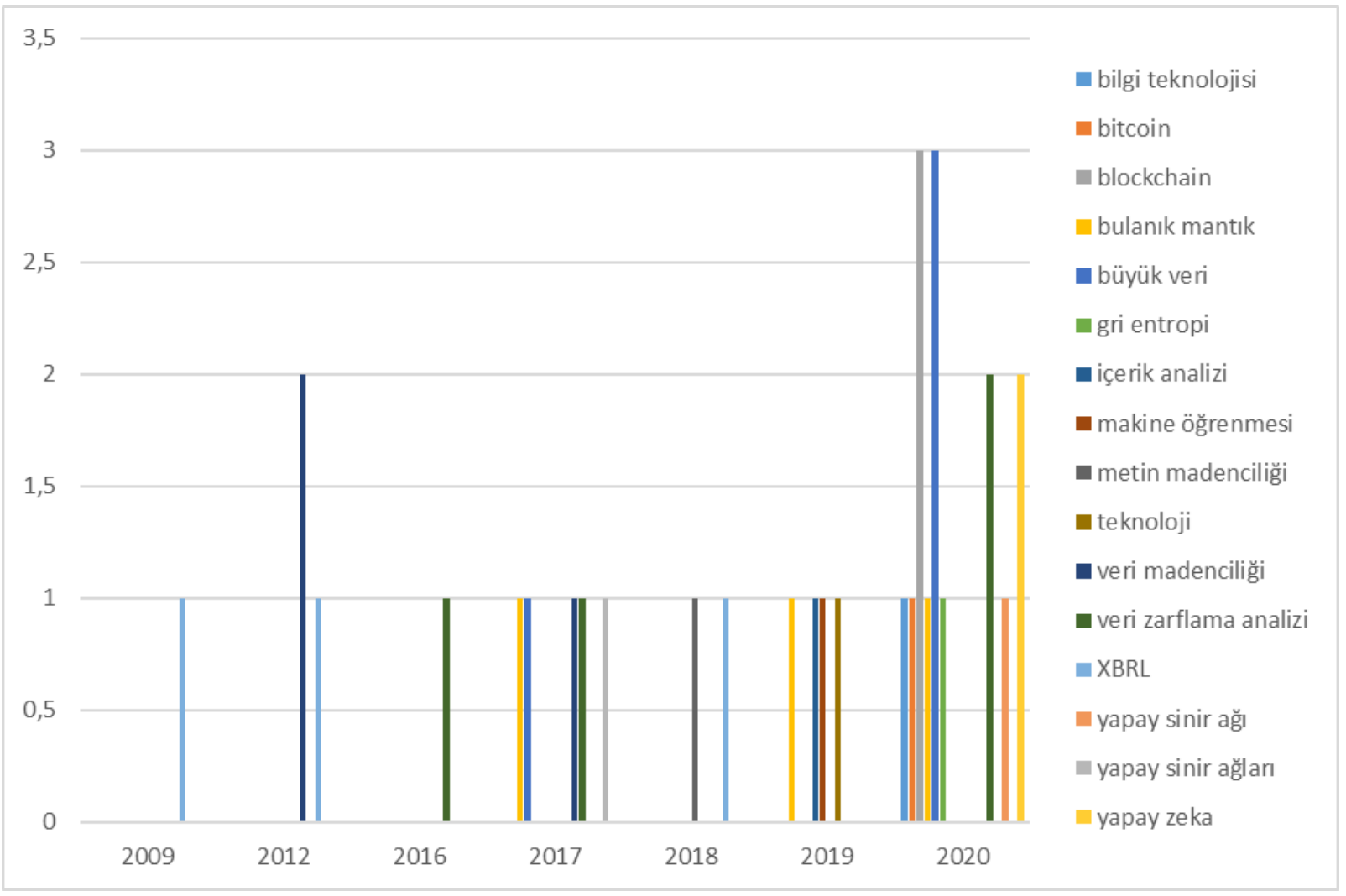


Yukarıda teknoloji odaklı anahtar kelimelerin her iki grupta farklı yıllar itibari ile başlanmış olsa da benze şekillerde değişim yaşandığı görülmektedir. Gerek JETA'da yer alan gerekse Türkçe çalışmalarda yer alan anahtar kelimeler ilgili literatürün geliştiği ilk yıllarda daha teknoloji, yapay zeka gibi genel ifadelerin yer aldığı daha çok ilgili alana yönelik teorik çalışmalardan oluşmaktadır (Geerts, 2004:73; Smeedley vd., 2004: 41; Vasarhelyi vd., 2004: 1; Çıtak, 2009: 1; Karabınar ve Yılmaz, 2012: 1).

Türkçe dizin her ne kadar erken dönemde uluslararası literatürün gerisinde kalmış gibi görünse de adaptasyonun gayet hızlı bir şekilde gerçekleştiği ve 2020'ye yaklaşırken çalışma sayılarının da arttığı görülmektedir. İncelenen konu çeşitliliğinin ise son yıllarda arttığı gözlenmektedir.

İlgili çalışmaların muhasebede hangi alanlara odaklandığını görmek için yıllar bazında muhasebeye ilişkin anahtar kelimeler incelendiğinde gerek JETA'da yayınlanan gerekse Dergi Park veri tabanında listelenen çalışmaların büyük bölümünün denetim alanında yapıldığı görülmektedir.

Grafik 4. Y1llara Göre Muhasebe Anahtar Kelimeleri- JETA

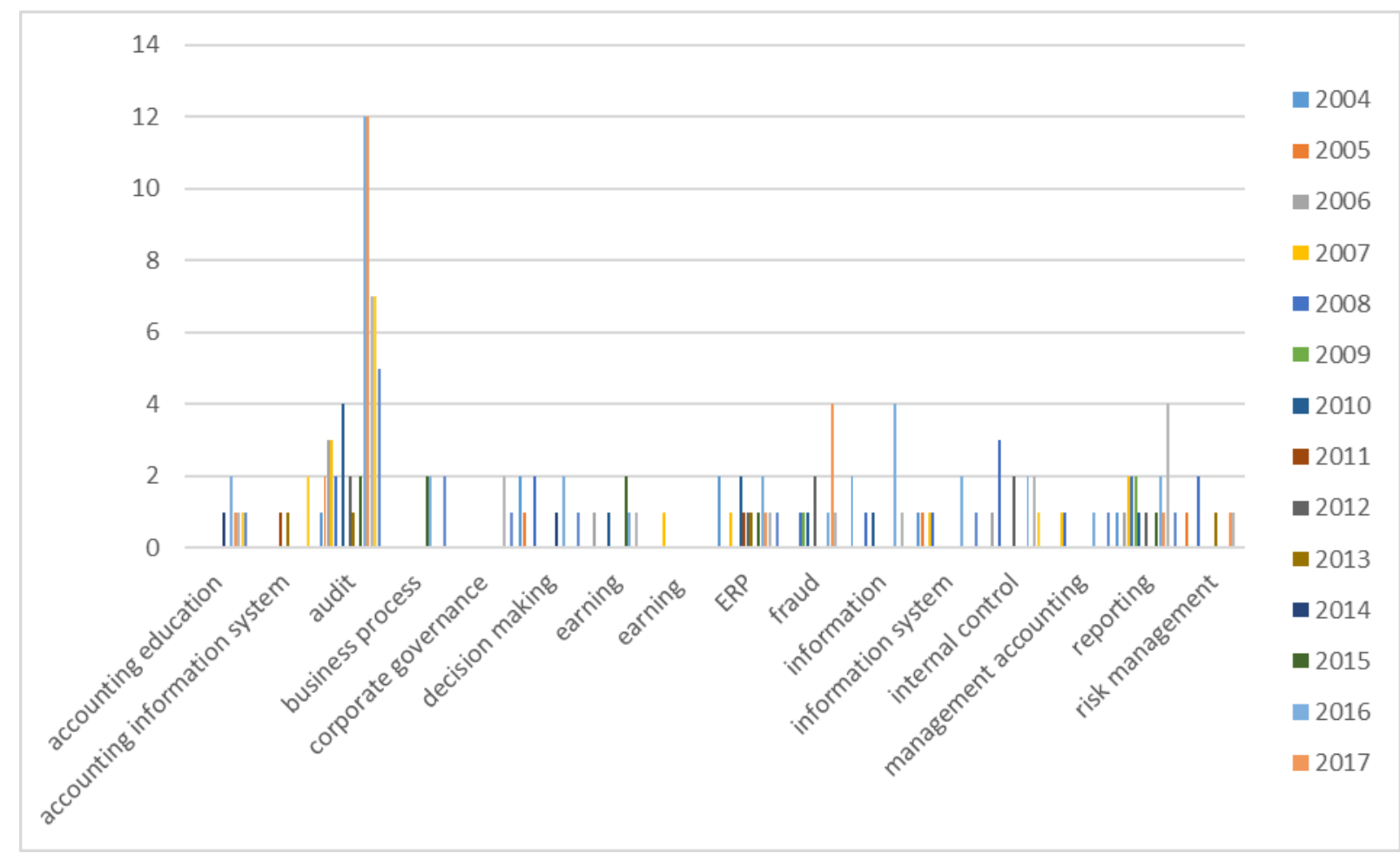

Çalışmalar incelendiğinde muhasebe alanında kullanılmış toplam 180 anahtar kelimeden 63 tanesinin denetimle ilgili olduğu görülmektedir. Çalışmaların detayına bakıldığında denetimin yapısal bir süreç olması sebebiyle denetim süreçlerinin teknoloji desteği ile daha düşük maliyetlerle gerçekleştirilmesi ve gerçek zamanlı ve/veya sürekli 
denetim gibi motivasyonlar öne çıkmaktadır (Teeter vd., 2010: 73; Santos vd., 2008: 37; Nigrini vd., 2008: 65).

Grafik 5. Yıllara Göre Muhasebe Anahtar Kelimeleri- Dergi Park

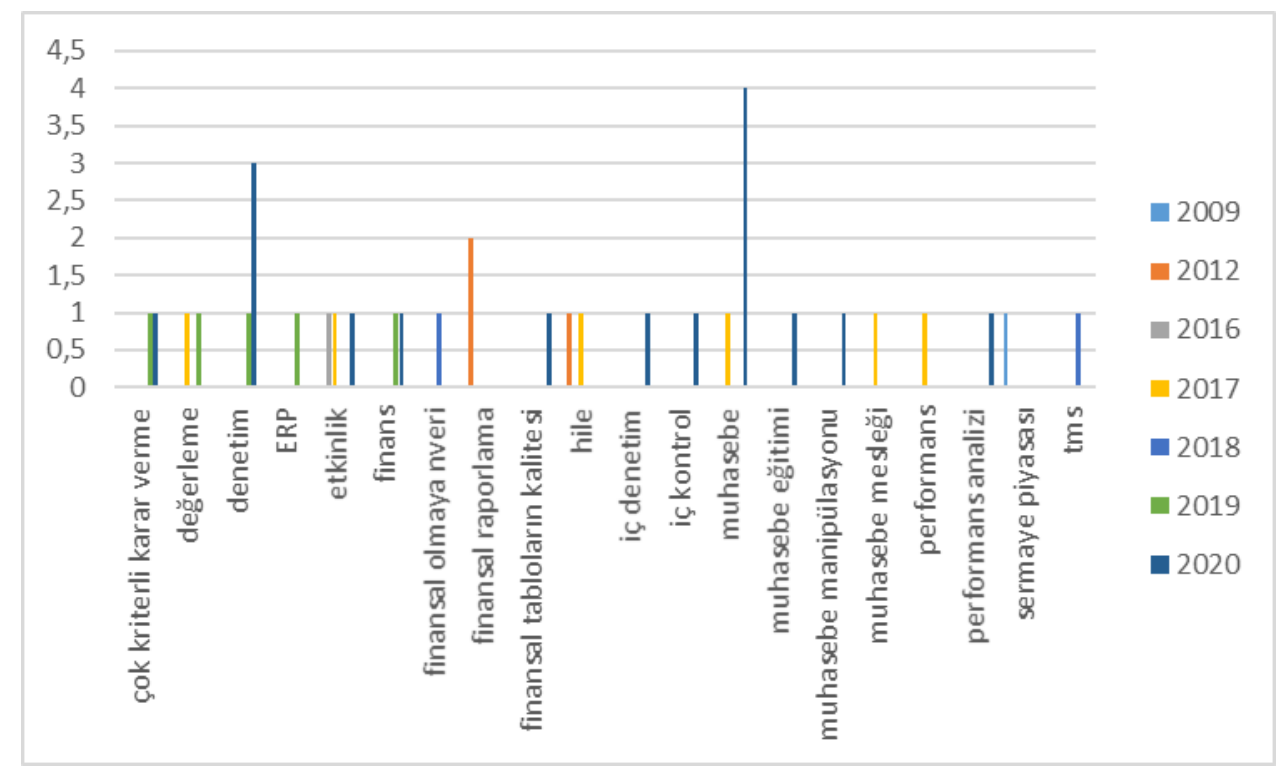

Dergi Park veri tabanında listelenen ilgili çalışmalara bakıldığında her ne kadar uluslararası dizinle uyumlu bir şekilde denetim konusunun öne çıktı̆̆ görülse de genel olarak muhasebe ifadesi öne çıkmaktadır. Bunun nedeni de yeni gelişen literatürün öncelikle teorik olarak ele alınması ve muhasebe gibi kapsamında pek çok alt uzmanlık barındıran bir mesleğin tüm yönlerine ilişkin genel değerlendirmesinin yapılması gösterilebilir.

\subsection{En Yaygın İşlenen Teknolojik Konular}

JETA'da listelenen çalışmalara bakıldığında teorik çalışmalarda muhasebe alanına yönelik ilk kez kullanılan yöntemlerin fayda/maliyet analizleri öne çıkmaktadır. Örneğin XBRL (Genişletilebilir İşletme Raporlama Dili [Extensible Business Reporting Language] zorunlu hale geldiğinde ilgili yöntemin kullanımında yaşanacak sıkıntılar ve bunlara yönelik çözüm önerileri sunulması (Henselmann vd.,2015: 117) veya muhasebenin örneğin denetim gibi bir alt uzmanlığında ne şekilde kullanılacağına ilişkin öneriler sunulması (Pinsker ve Felden, 2016:95; Fisher, IE; Nehmer, 2016:129; Boritz ve No, 2016:53) şeklinde çalışmalar olduğu görülmektedir. Öte yandan, gelişen teknolojinin muhasebeciler özelinde hızla uyum sağlayamayacağ 1 ön görüsü, açık veri kaynaklarından finansal verinin ne şekilde elde edileceğinin detaylıca açıklandığı çalışmaların öne çıkmasında etkili olmuştur (Krotov ve Tennyson, 2018:169). Aynı konu özelinde çeşitli veri setlerinin incelenmesi ya da vaka incelemeleri yoluyla ampirik bulgulara yer verildiği görülmektedir (Du ve Wu, 2018:57; Pinsker ve Felden, 2015:95; Hsieh ve Bedard, 2018: 45; Hao vd., 2013:41).

XBRL özelinde belirtmek gerekirse 2014 yılında Amerika Birleşik Devletleri'nde Dijital Hesap verebilirlik ve Şeffaflık Yasası'nın (Digital Accountability and Transparency Act of 2014 [DATA Act]) yürürlüğe girmesinin hemen ardından (Errichetti ve Roohani, 
2018:107) muhasebe literatüründe çok daha yaygın biçimde gündeme geldiği, fayda ve maliyetinin, kısıtlarının teorik olarak değerlendirildiği, devam eden süreçte de ampirik bulgularla uygulamadaki çeşitli dinamikler arasındaki sebep-sonuç ilişkilerinin incelendiği görülmektedir. Muhasebe araştırmaları açısından bakılacak olursa bu süreç teknoloji gibi hızla değişen bir fenomen özelinde herhangi bir olgunun ya da uygulamanın akademik araştırmalar açısından yaşam evresine iyi bir örnek olarak sunulabilir.

Türkçe literatürde elde edilen sınırlı sayıdaki çalışma esasen benzer bir süreçten geçmiş ve uluslararası literatürün tarihler itibari ile gerisinde kalmamıştır. İncelenen Türkçe çalışmalardan üç tanesi muhasebe ve XBRL konusunu işlemiştir. Çıtak (2009), İngilizce literatürü incelemiş ve dünyada XBRL'nin muhasebe alanındaki uygulamalarına yönelik zengin bir dizin sunmuştur. Akabinde Karabınar (2012) kapsamlı bir çalışma ile ilgili konunun önemini, finansal raporlamada yaratacağı etkileri detaylı biçimde ele almıştır. (Poroy ve diğerleri (2018) ise kullanıcı görüşlerine yer vermek suretiyle sistemsel fayda ve aksaklıklara 1şık tutacak ampirik bilgiler sunmuştur.

Bir diğer popüler konu olan büyük veri sıklıkla denetim konusu ile birlikte işlenmiştir. Teorik çalışmalarda büyük verinin veri güvenilirliği açısından kısıtları (Appelbaum, 2016:17), büyük verinin veri analizinde ne şekilde kullanılabileceği (Razaee vd.,2018:183) açıklanmıştır. Teknolojideki hızlı gelişim ve değişimin muhasebe gibi standartlar ve sistematik yapılar çerçevesinde şekillenmiş bir disipline entegrasyonu muhasebe meslek mensubu ve uzmanların mühendislik kökenli olması çok beklenemeyeceğinden ancak muhasebe eğitimlerine entegrasyon ile mümkün olabilir. Buna uygun olarak literatürde büyük verinin muhasebe alanında kullanımına yönelik öğretim vakaları (teaching case) akademik çalışma şeklinde sunulmuştur (Flasher, 2019:57; Weirich vd., 2018:137).

Aslan ve Özerhan (2017) büyük verinin gelecekte muhasebe mesleğinde kullanımına ilişkin olarak meslek mensuplarının görüşleri incelendikleri çalışma ile meslek mensuplarının konuya ilişkin vizyonuna 1 şı tutmuştur. Ucoğlu (2020) AACSB akredite üniversitelerin muhasebe programlarını incelemiş ve muhasebe alanına da sirayet eden çeşitli teknolojilerin muhasebe eğitimine ne şekilde adapte edildiğine yönelik ampirik bilgiler sunmuştur. A ğdeniz ve Yıldız (2018) büyük verinin büyük oranda yapısal olmayan veriden oluşması nedeniyle istatistiksel analizlerde nasıl hatalı sonuçlar doğurabileceğine işaret etmişlerdir. Onay (2020) ve Yılmaz (2020) ise büyük verinin iç denetim/denetim faaliyetlerinde ne şekilde kullanılabileceğini teorik ve kavramsal olarak açıklamıştır. Şener vd. (2020) büyük verinin işletmelerdeki kullanımına yönelik gerçekleştirdikleri ampirik çalışmada işletmelerin ilgili teknolojinin adaptasyonunda bulundukları evreyi tespit etmeye çalışmıştır.

En fazla işlenen teknolojik konulardan bir diğeri olan yapay zeka gerek JETA gerekse Dergi Park çalışmalarında genel olarak ele alındığı gibi yapay sinir ağları ya da uzman sistemler gibi alt dalları ile de ele alınmıştır. JETA çalışmalarına bakıldığında yapay zekanın muhasebe ve denetim alanında ne şekilde kullanılabileceğine yönelik kavramsal açıklamaların ve önermelerin yapıldığı teorik çalışmalar öne çıkmaktadır (Boritz vd.,2016:145; Harris vd., 2019:71; Tapis ve Priya, 2018:133; Smedley vd., 2004:41).

Muhasebe işlemlerinde görev otomasyonu sağlayan sistem önerileri (Eliot vd., 2018:51); denetimde ilgili uygulamalara yönelik öneriler (Alawadi ve Byrnes, 2019:65), 
yönetsel kararlarda makine öğrenmesi gibi yapay zeka uzmanlıklarının ne şekilde kullanılabileceğine dair önermeler (Chou vd., 2020:1) öne çıkmaktadır.

Spesifik uygulamalarda yapay zekanın en öne çıktığı alan ise yapay sinir ağları yöntemidir. Yapay sinir ağları yöntemi makine öğrenmesine dayalı bir şekilde muhasebenin denetim, yönetim, finansal analiz gibi her türlü alt uzmanlığına ilişkin en önemli faaliyetlerden biri olan tahmin yürütmede bir sistematik olarak karşımıza çıkmaktadır. Teorik olarak incelenen çalışmalarda finansal tablo hilelerinin tespiti (Mckee, 2009:5), geçmiş yıl verisinin tahminlerde bir öğrenme modeli olarak ne şekilde tasarlanabileceği (Koskivaara ve Back, 2007:29) konuları öne çıkmaktadır.

Ampirik çalışmalarda ise sinir ağları yöntemiyle denetim sürecinde karar ağaçları oluşturulması (Garnsey, 2006:21; Geerts, 2007:161), kazanç tahminlerinde manuel tahminlerle yapay sinir ağı modelleriyle tahminleme arasındaki farkın tespiti ve yapay zekaya dayalı yöntemin daha doğru tahminlerde bulunduğunun ispatı (Shawver, 2005:61; Ragothaman vd., 2008:129; O'Brien ve Stone, 2018:21) yer almaktadır.

Türkçe literatüre bakıldığında yapay zeka ve ilgili uygulamaların yapay zeka teknolojisinin geçmişten günümüze muhasebe alanında gelişiminin literatüre dayalı olarak değerlendirilmesi (Kütük ve Zor, 2020:193), denetim alanında yapay zeka ve spesifik olarak makine öğrenmesi konularına yönelik ayrıntılı literatür incelemesi (Taş ve Mert, 2019:65), Finansal başarı/başarısızlık tahminlerinde yapay sinir ağları yönteminin ne şekilde kullanılabileceğine ilişsin yol haritası sunulması (Söylemez ve Yılmaz Türkmen, 2017:270) çalışmaları öne çıkmaktadır.

Ampirik çalışmalara bakıldı̆̆ında manipülatif şirketlerin sınıflandırmasında kullanılması (Kara ve Özcan, 2020: 156), muhasebe eğitiminde yapay zeka teknolojisine yer verildiği eğitim programlarının incelenmesi (Ucoğlu, 2020:16) ve yapay sinir ağları yöntemi ile etkinlik tahmini yapılan (Demirkol vd., 2020:500) çalışmaları göze çarpmaktadır.

Son yılların en popüler konularından birisi haline gelen ve çokça tartışmaya konu olan blockchain teknolojisi de bir diğer popüler teknolojik konu olarak muhasebe literatüründe yerini almıştır. JETA çalışmalarına bakıldığında denetim alanında blockchain teknolojisi ile otomasyona dayalı iş süreçleri oluşturulması ve harici denetim blok zincirleri ile denetimde tüm paydaşların beklentilerinin optimum düzeyde karşılanacağı bir denetim modeli yaratmanın mümkün olacağı önerilmekte (Byrnes, 2019:65; Rozario ve Thomas, 2019:21), ilgili teknolojinin muhasebe alanında kullanımından sağlanacak faydaların ve kısıtların ele alındığ teorik önermeler yapılmakta (Appelbaum, 2017:99; Lombardi ve Dull, 2016:37), en üst düzey veri güvenliği sağlamak için blok zincir teknolojisinden ne şekilden faydalanılabileceği teorik olarak açıklanmakta (Dai vd., 2019:1), muhasebe eğitiminde blok zincir teknolojisinin ne şekilde müfredata eklenmesi gerektiği belirtilmekte (Marshall ve Lambert, 2020:37), muhasebe alanında ilgili teknolojinin potansiyeli kavramsal olarak açıklanmaktadır (Kokina vd., 2017:91; Coyne ve McMickle, 2017:101). Öte yandan henüz ampirik herhangi bir çalışmaya rastlanmamıştır.

Türkçe literatüre bakıldığında blok zincir teknolojisinin ne şekilde uygulanacağına dair net bir öneri ya da örnek bulunmaması motivasyonu ile denetim alanında ilgili teknolojinin ele alındığı akademik çalışmaların uluslararası literatür esas alınarak derlenmiş 
(Cagle, 2020:695), ticari birliklerin işletmelerin blok zincir teknolojisi uygulamalarındaki rolüne değinilmiştir (Uzun, 2020:88). Ayrıca blok zincir teknolojisine dayalı gelişen kripto paraların ne şekilde muhasebeleşeceği ve raporlanabileceği standartlar ve ilgili mevzuat çerçevesinde kavramsal olarak değerlendirilmiş (Özkul ve Baş, 2020:218), blok zincir teknolojisinin muhasebe ve denetim alanında nasıl bir etki yaratacağı kavramsal olarak tartı̧̧1mıştır (Kılınç, 2020:989).

Son olarak öne çıkan bir diğer teknolojik konu ver madenciliği yöntemidir. Veri madenciliği yapısal olmayan ya da yapısal olmasına karşın içerdiği farklı faktörler bir şekilde birbiriyle ilişkilendirilmiş olmayan büyük ölçekli veri setlerinde saklı kalmış ilişki ağlarını ortaya çıkartması bakımından sıklıkla denetim alanında ön plana çıkmıştır (Jans, 2019:59; Zhang, 2019:69; Byrnes, 2019:65). Öte yandan veri madenciliğinin muhasebenin geleceğini ne şekilde şekillendireceği ve muhasebe eğitimdeki yeri tartı̧̧ılmışır (Palmer ve Gupta, 2011:65). Ampirik çalışmalara bakıldığında kalitatif ve kantitatif bilgilerinin birbiri ile ne kadar tutarlı olduğunu ölçmek için veri madenciliği yöntemine başvurulduğu (Chou vd., 2018:93), ilgili yöntem ile şirket final pozisyonu ve iflas tahminlerinin (Shirata, 2011:31) ve şirket süreklilik tahminlerinin (Shirata vd., 2008:1) yapıldığı, tahmin algoritmaları geliştirmek suretiyle yazılı şirket bilgilendirmelerinden kazanç tahminleri yapıldığı (Henry, 2006:1) görülmektedir.

Türkçe literatüre bakıldığında hile denetiminde veri madenciliği ve diğer teknolojik yeniliklerin kullanımına ilişkin teorik bilgiler sunulduğu (Ertikin, 2017:71), metin madenciliği yönteminin muhasebe alanında ne şekilde kullanılabileceğine ilişkin teorik bilgilerin sunulduğu (Ağdeniz ve Yıldız, 2018:286), çalışmalar göze çarpmaktadır.

Ampirik çalışmalara bakıldığında; hile riski bulunan firmaların tespitinde (Terzi ve Şen, 2017:25) ve hile denetiminde (Akyel ve Seçkin, 2012:21) veri madenciliğinin kullanıldı̆̆ı, karar ağacı yöntemi ile firmaların etkinlik düzeylerine etki eden finansal değişkenlerin belirlendiği (Dayı ve Sezgin Alp, 2020:185), içerik analizi ile finansal tabloların incelenmesi suretiyle gerçeğe uygun değer muhasebesinin kullanım boyutunun incelendiği (Cebeci ve Gökçen, 2019:196) görülmektedir.

Aşağıdaki tabloda genel olarak en öne çıkan teknoloji odaklı konular ile bu konuların işlendiği JETA ve DergiPark yayınları çalışma kapsamı ve yöntemine göre sunulmuştur.

Tablo 3. JETA ve DergiPark'da Öne Çıkan Teknoloji Konuları ve İlgili Yayınlar

\begin{tabular}{|c|c|c|c|}
\hline $\begin{array}{c}\text { Teknoloji } \\
\text { Odağı }\end{array}$ & Kaynak & Muhasebe Konusu & $\begin{array}{c}\text { Araştırma } \\
\text { Yöntemi }\end{array}$ \\
\hline 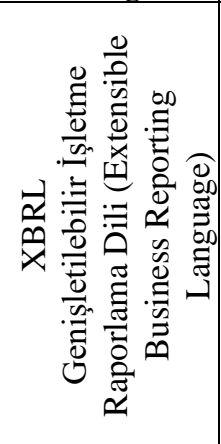 & 画 & $\begin{array}{l}\text { Zorunlu XBRL kullanımında karşlaşılacak sorunların tespiti ve çözüm } \\
\text { önerileri (Henselmann vd.,2015) } \\
\text { Denetim gibi muhasebe alt uzmanlıklarında XBRL'nin ne şekilde } \\
\text { kullanılacağına ilişkin öneriler Pinsker ve Felden, 2016; Fisher, IE; } \\
\text { Nehmer, 2016; Boritz ve No, 2016) } \\
\text { Açık veri kaynaklarından muhasebe verisinin elde edilmesi (Krotov ve } \\
\text { Tennyson, 2018) } \\
\text { Zorunlu XBRL kullanımının finansal raporlama sürecine etkisi (Du ve }\end{array}$ & Teorik \\
\hline
\end{tabular}




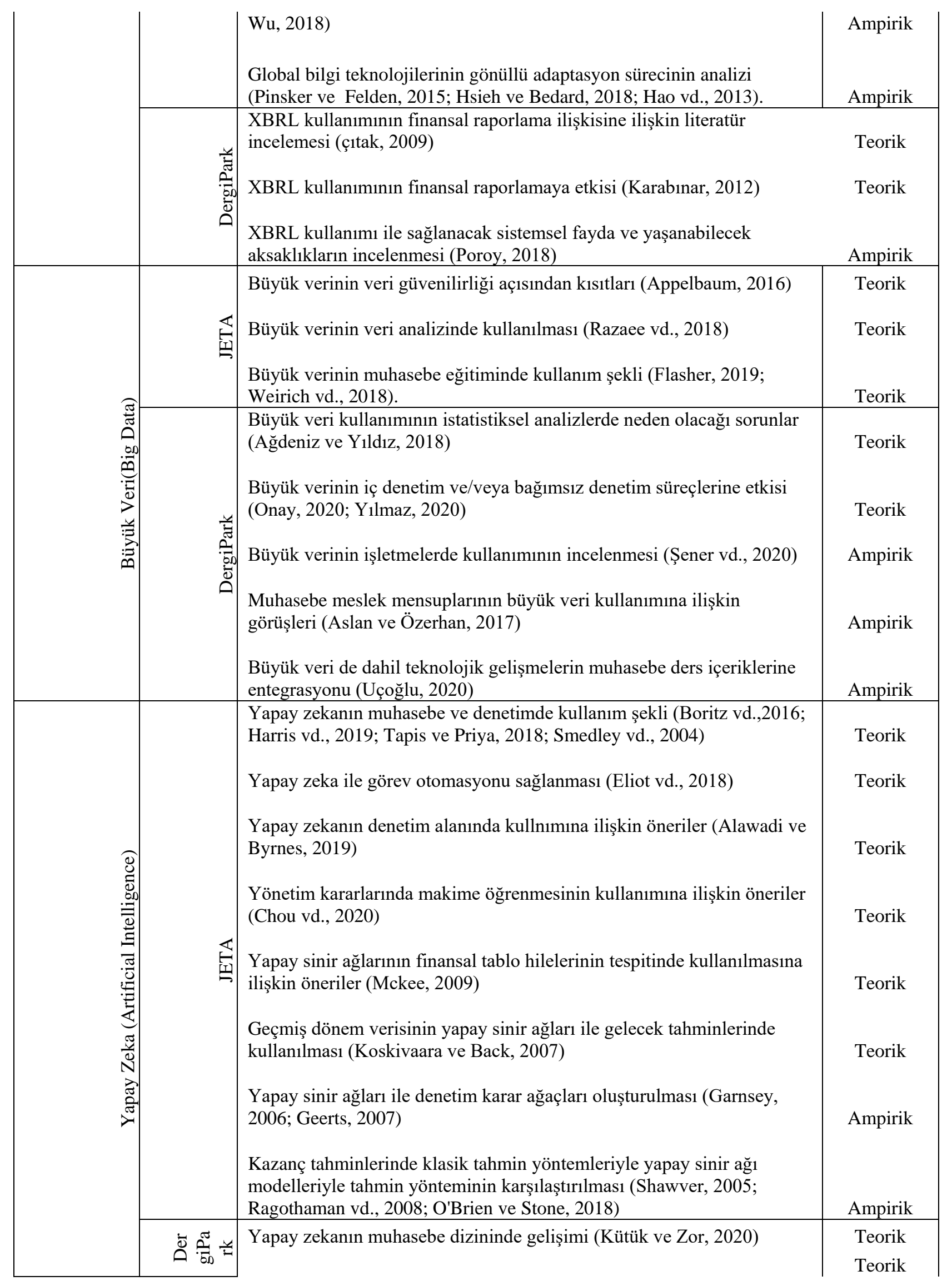




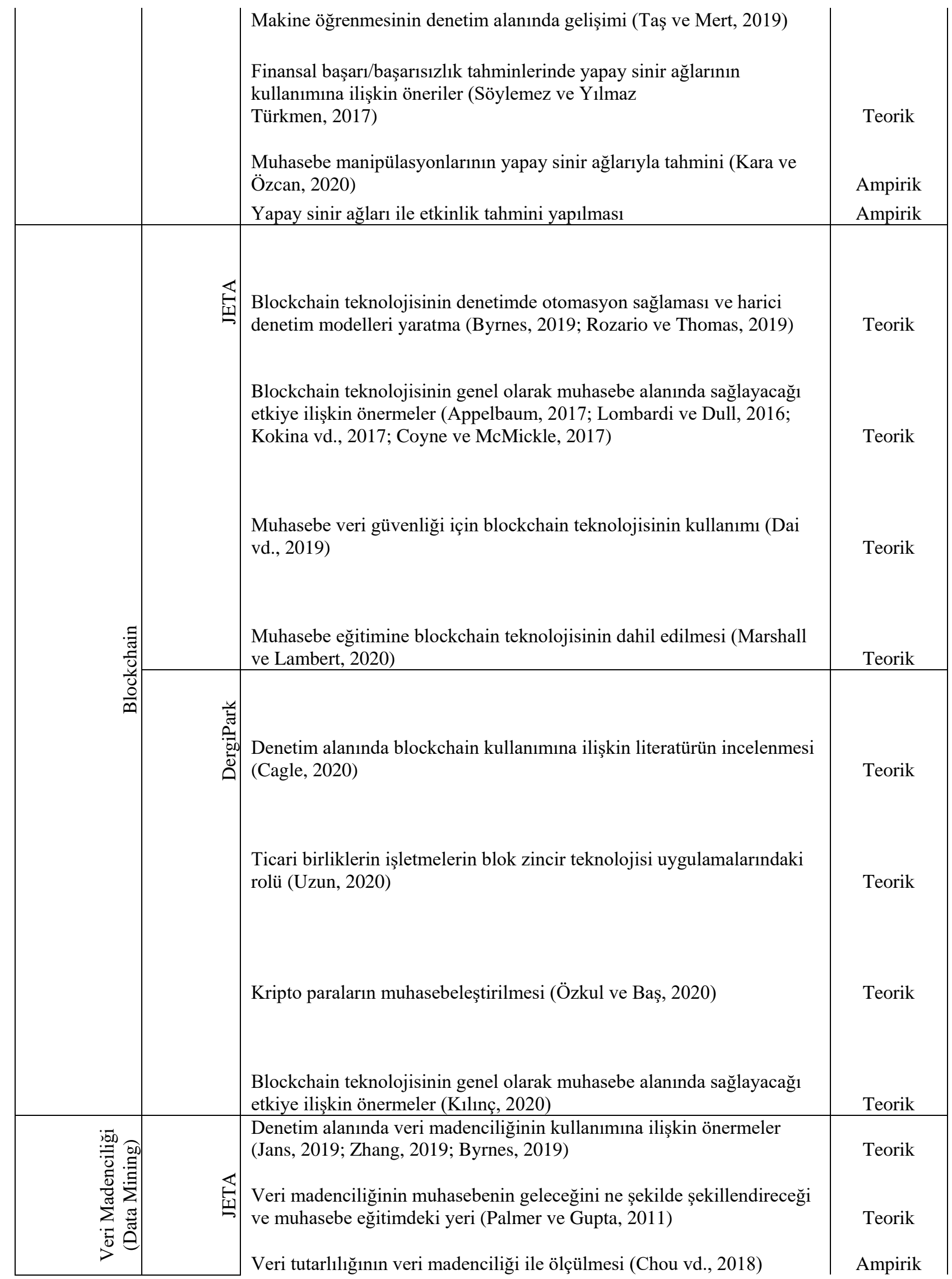




\begin{tabular}{|c|c|c|}
\hline & $\begin{array}{l}\text { Final pozisyonu, işletme sürekliliği ve iflas tahminlerinde veri } \\
\text { madenciliği kullanımı (Shirata, 2011) } \\
\text { Tahmin algoritmalarıyla yazılı şirket bilgilendirmelerinden kazanç } \\
\text { tahminleri yapılması (Henry, 2006) }\end{array}$ & Ampirik \\
\hline 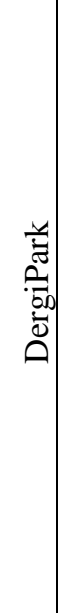 & $\begin{array}{l}\text { Hile denetiminde veri madenciliği kullanımı (Ertikin, 2017) } \\
\text { Metin madenciliği yönteminin muhasebe alanında kullanılması (Ağdeniz } \\
\text { ve Yıldız, 2018) } \\
\text { Hile riski bulunan firmaların veri madenciliği ile tespit edilmesi (Terzi } \\
\text { ve Şen, 2017) } \\
\text { Hile denetiminde veri madenciliğinin kullanılması (Akyel ve Seçkin, } \\
\text { 2012) } \\
\text { Karar ağacı yönteminin etkinlik düzeyine etki eden finansal } \\
\text { değişkenlerin belirlenmesinde kullanılması (Dayı ve Sezgin Alp, 2020) } \\
\text { İçerik analizi ile finansal tabloların incelenmesi (Cebeci ve Gökçen, } \\
\text { 2019) }\end{array}$ & $\begin{array}{l}\text { Teorik } \\
\text { Teorik } \\
\text { Ampirik } \\
\text { Ampirik } \\
\text { Ampirik } \\
\text { Ampirik }\end{array}$ \\
\hline
\end{tabular}

Türkçe literatürde incelenen diğer konular ise genel olarak bilgi teknolojilerinin ele alındığ1 (Demirel ve Eris, 2019:226), bulanık çok kriterli karar verme yönteminin literatür incelemesi şeklinde (Koca ve Yıldırım, 2020:257), kurumsal kaynak planlaması (ERP) gibi sofistike uygulamalara entegre edilmesinin teorik olarak tartışılması (Sağnak ve Kazancıoğlu, 2019:75) şeklinde değerlendirildiği çalışmalar ile ilgili yöntemi kullanmak suretiyle marka değerlemesi yapılan ampirik bulguların sunulması (Karataş Aracı ve Bekçi, 2017:31) şeklinde çalışmalar göze çarpmaktadır.

JETA ve Dergi Parkta veri tabanında yapılan sistematik literatür taramasında öne çıkan önemli bir bulgu olarak Türkçe dizinde henüz hiç işlenmemiş teknolojik konular gösterilebilir. Özellikle JETA'da çok sayıda çalışmada konu edilmesine karşın Türkçe dizinde rastlanmayan veri analitiği konusunun gerek teorik olarak gerek muhasebe eğitimindeki yeri bakımından gerekse örnek teşkil etmesi açısından örneğin finansal analiz, denetim gibi alanlarda ampirik olarak sunulması Türkçe dizine katkı sağlayacaktır.

Bir diğer göze çarpan husus ise pek çok teknolojik yenilik için İngilizce literatürde muhasebe eğitimine ilgili konunun entegrasyonu gündeme gelirken ve ilgili alanda muhasebe derslerinde işlenebilecek vaka örnekleri sunulurken Türkçe dizinin bundan istifade etmesi beklenmektedir.

\section{SONUÇ}

İnsan faktörünün değişime karşı önemli bir etkisi olduğu için, teknolojik değişimlerin etkileri, değişimin gerçekleştiği organizasyonel ve kültürel bağlamlar içinde düşünülmelidir. Teknoloji ve muhasebe disiplininin uyumu esasen en baştan tartışmalı olabilir zira muhasebe sosyal bir bilim alanı olarak alandaki uzmanların ayrıca bir mühendislik bilgi ve becerisine 
sahip olması elbette ki beklenemez. Öte yandan, günümüzden 50 yıl kadar önce tamamı kağıt kalemle yapılan muhasebe işlemlerinin bugün bilgisayar ortamına taşınmış olması ve günümüzde muhasebeye ilişkin her türlü teorik bilgiye sahip olan bir meslek mensubunun bilgisayar becerisine sahip olmaksızın neredeyse hiçbir şey yapamayacak olması gelecekte muhasebecilerin karşılaşması olası senaryoya da 1şık tutabilir. Dolayısıyla muhasebenin bir sosyal bilim olması teknolojik yeniliklerin adapte edilmemesi için bir gerekçe olamaz.

Elbette muhasebe alanında uzmanların teknolojik yenilikleri adapte edebilir hale gelmesi alacakları eğitimle doğrudan ilişkilidir. Bu bakımdan ilgili teknolojik yeniliklerin ilk olarak muhasebe eğitimine adapte edilmesi gerekir. Bunun için ise alandaki akademisyenlerin ilgili alanlara yönelik kendilerini geliştirmelerine, araştırma yapmalarına, eğitim programları tasarlamalarına ve öncü adımlar atmasına ihtiyaç vardır.

Bir diğer göze çarpan husus JETA hali hazırda teknoloji-muhasebe odaklı bir dergi olmasına karşın rutin bir şekilde konu spesifik araştırma çağrıları yapmaktadır. Türkçe literatürde alana özel bir muhasebe dergisi bulunmasa dahi mevcut muhasebe dergilerinde konu spesifik araştırma çağrıları açılması alanda çalışan akademisyenler için bir motivasyon unsuru ve literatürün geliştirilmesinde tetikleyici bir etki yaratabilir.

Bu çalışmanın amacı uluslararası literatür ve Türkçe literatürün karşılıklı incelenmesi suretiyle teknoloji-muhasebe ilişkisine sistematik bir 1şık tutmaktır. Amacına uygun olarak elde edilen bulgular göstermektedir ki alana ilişkin literatür büyük ölçüde teorik çalışmadan oluşmaktır. Yeni bir fenomenin ilk olarak teorik olarak ele alınması ve sonra çeşitli uygulamalarla ampirik bulgulara yer verilmesi, akabinde ilgili konunun alana yönelik eğitim açısından değerlendirilmesi ve gelecek uygulamalara yönelik önerilerde bulunması teknolojimuhasebe literatürünün yaşam evresini oluşturmaktadır. Bu bakımdan bundan sonra ortaya çıkabilecek teknolojik yeniliklerde ve/veya veri analitiği gibi Türkçe muhasebe literatüründe henüz konu edilmemiş uygulamaların akademik araştırmalara konu edilmesinde izlenecek yol haritası bakımından önemli bir ışık tutmaktadır.

\section{KAYNAKLAR}

Ağdeniz, Şafak - Yıldız, Birol (2018), "Muhasebede Analiz Yöntemi Olarak Metin Madenciliği”, Muhasebe Bilim Dünyası Dergisi, 20 (2), ss. 286-315.

Akyel, Nermin - Seçkin, Keziban (2012), "K-En Yakın Komşuluk Algoritmasının Hile Denetiminde Kullanımı", Muhasebe ve Vergi Uygulamaları Dergisi, (1), ss. 21-40.

Alawadhi, Abdullah - Byrnes, Paul (2019), "Clustering University Programs in Accounting to Enhance Selection Productivity: Precursor to Recommendation System Development” Journal of Emerging Technologies in Accounting, 16 (1), pp. 65-79.

Appelbaum, Deniz (2016), "Securing Big Data Provenance for Auditors: The Big Data Provenance Black Box as Reliable Evidence”, Journal of Emerging Technologies in Accounting, 13 (1), pp. 17-36.

Appelbaum, Deniz - Nehmer, Robert (2017), “Using Drones in Internal and External Audits: An Exploratory Framework” , Journal of Emerging Technologies in Accounting, 14 (1), pp. 99-113.

Aslan, Ümmühan - Özerhan, Yıldız (2017), "Big Data, Muhasebe Ve Muhasebe Mesleği”, Muhasebe Bilim Dünyası Dergisi Aralık,19(4), ss. 862-883 
Boritz, J. Efrim - No, Won, Gyun (2016), “Computer-Assisted Functions for Auditing XBRLRelated Documents”, Journal of Emerging Technologies in Accounting, 13 (1), pp. 53-83.

Boritz, J. Efrim - Hayes, Louise - Timoshenko Lev M. (2016), "Determinants of the Readability of SOX 404 Reports", Journal of Emerging Technologies in Accounting,13 (2), pp. 145-168.

Cagle, Melisa (2020), “A Mapping Analysis of Blockchain Applications Within The Field of Auditing”, Muhasebe Bilim Dünyası Dergisi, 22 (4), ss. 695-724.

Cebeci, Yasin - Gökçen, Gürbüz (2019), "Gerçeğe Uygun Değer Hiyerarşisine İlişkin Borsa İstanbul'da İçerik Analizi", Journal of Research in Business, 4 (2), ss. 196-215. Retrieved from https://dergipark.org.tr/tr/pub/jrb/issue/50165/630873

Chou, Chi-Chun - Chang, Janie - Chin, Chen-Lung - Chiang, Wei-Ta (2018), "Measuring the Consistency of Quantitative and Qualitative Information in Financial Reports: A Design Science Approach”, Journal of Emerging Technologies in Accounting, 15 (2), pp. 93-109.

Coyne, Joshua, G. - McMickle, Peter, L. (2017), "Can Blockchains Serve an Accounting Purpose?” Journal of Emerging Technologies in Accounting, 14 (2), pp. 101-111.

Çıtak, Nermin (2009), "Güvenilir Finansal Raporlama Açısından Genişletilebilir İşletme Raporlama Dilinin (XBRL) Önemi Ve Dünya Ülkelerindeki Uygulaması”, Muhasebe ve Vergi Uygulamaları Dergisi, 2009-2, ss.1.-19.

Day1, Faruk- Sezgin Alp, Özge (2020), "Havayolu Şirketlerinde Etkinlik Tahmini: Asya Pasifik Şirketlerinde Bir Uygulama”, Muhasebe ve Finansman Dergisi, 86, ss. 185204.

Demirel, Demokaan - Eris, Vedat (2019), "Bankacılık ve Finansal Hizmetlerde Yenilikçilik Ve Teknoloji Uygulamaları: Türkiye İş Bankası Örneği”, PressAcademia Procedia, 9 (1), ss. 226-230.

Demirkol, İsa - Köksal, İmdat - Çiçek, Ali (2020), “Türkiye Şeker Fabrikalarının Üretim Ve Nakit Yönetimi Süreçlerinin Veri Zarflama Analizi İle Araştırılması”, Academic Review of Humanities and Social Sciences, 3 (2), ss. 500-516.

Du, Hui - Wu, Kean (2018), “XBRL Mandate and Timeliness of Financial Reporting: Do XBRL Filings Take Longer?”, Journal of Emerging Technologies in Accounting, 15 (1), pp. 57-75.

Eliot, Victor - Paananen, Mari - Staron, Miroslaw (2019), “Artificial Intelligence for Decision-Makers”, Journal of Emerging Technologies in Accounting, 17 (1), pp. 5155.

Errichetti, Jacob - Roohani, Saeed, J. (2018), “The Merit of the DATA Act to Enhance the Governmental Reporting Process: A Corporate Governance Perspective”, Journal of Emerging Technologies in Accounting, 15 (1), pp. 107-120.

Ertikin, Kıvanç (2017), "Hile Denetimi: Kırmızı Bayrakların Tespiti için Kullanılan Proaktif Yaklaşımlar”, Muhasebe ve Finansman Dergisi, (75), ss. 71-94.

Fisher, Ingrid, E. -. Nehmer, Robert A. (2016), "Using Language Processing to Evaluate the Equivalency of the FASB and IASB Standards”, Journal of Emerging Technologies in Accounting, 13 (2). Pp. 129-144.

Flasher, Renee (2019), "Sunshine to Government-Opportunities for Engagement with Government Data” Journal of Emerging Technologies in Accounting, 17 (1), pp. 5762. 
Garnsey, Margaret, R. (2006), “Automatic Classification of Financial Accounting Concepts”, Journal of Emerging Technologies in Accounting, 3 (1), pp. 21-39.

Geerts, Guido, L. (2004), “An XML Architecture for Operational Enterprise Ontologies”, Journal of Emerging Technologies in Accounting 1(1), pp. 73-90.

Geerts, Guido, L. - Wang, Harry, Jiannan (2007), “The Timeless Way of Building REA Enterprise Systems.”, Journal of Emerging Technologies in Accounting, 4 (1), pp. 161-182.

Hao, Lizhong - Kohlbeck, Mark J. (2013), "The Market Impact of Mandatory Interactive Data: Evidence from Bank Regulatory XBRL Filings", Journal of Emerging Technologies in Accounting, 10 (1), pp. 41-62.

Harris, Megan - Riley, Jennifer - Venkatesh, Roopa (2019), "Psychological Capital and Robotic Process Automation: Good, Bad, or Somewhere In-Between?”, Journal of Emerging Technologies in Accounting, 17 (1), pp. 71-76.

Henry, Elaine (2006), "Market Reaction to Verbal Components of Earnings Press Releases: Event Study Using a Predictive Algorithm” Journal of Emerging Technologies in Accounting, 3 (1), pp. 1-19.

Henselmann, Klaus - Ditter, Dominik - Scherr, Elisabeth (2015), "Irregularities in Accounting Numbers and Earnings Management-A Novel Approach Based on SEC XBRL Filings”, Journal of Emerging Technologies in Accounting (2015) 12 (1): i-vii, pp. 117-152.

Hopwood, Anthony, G. (1990), “Accounting and Organisation Change”. Accounting, Auditing and Accountability Journal. Vol. 3, No. 1.

Hsieh, Tienshih - Bedard, Jean (2018), "Impact of XBRL on Voluntary Adopters' Financial Reporting Quality and Cost of Equity Capital”, Journal of Emerging Technologies in Accounting, 15 (2), pp. 45-65.

Jans, Mieke (2019), “Auditor Choices during Event Log Building for Process Mining”, Journal of Emerging Technologies in Accounting, 16 (2), pp. 59-67.

Kara, Suat - Özcan, Pelin (2020), "Muhasebe Manipülasyonlarında Yapay Sinir Ağlarının Önemi ve Bir Uygulama”, Muhasebe ve Denetime Bakış, 20 (60), 155-176.

Koskivaara, Eija - Back, Barbro (2007), "Artificial Neural Network Assistant (ANNA) for Continuous Auditing and Monitoring of Financial Data.”, Journal of Emerging Technologies in Accounting, 4 (1), pp. 29-45.

Kotb, Amr - Abdel-Kader, Magdy - Allam, Amir - Halabi, Hussein- Franklin, Ellie (2019), "Information Technology In The British And Irish Undergraduate Accounting Degrees”. Accounting Education, 28(5), pp. 445-464.

Krotov, Vlad - Tennyson, Matthew (2018), "Research Note: Scraping Financial Data from the Web Using the R Language”, Journal of Emerging Technologies in Accounting, 15 (1), pp. 169-181.

Luhn, Hans, Peter (1958), “A Business Intelligence System”. IBM Journal, pp. 314-319.

Moffitt, Kevin - Vasarhelyi, Miklos, A. (2013), “AIS In An Age Of Big Data”, Journal of Information Systems. 27 (2), pp. 1-19.

Qasim, Amer - Kharbat, Faten, F. (2019), "Blockchain Technology, Business Data Analytics, And Artificial İntelligence: Use In The Accounting Profession And Ideas For Inclusion Into The Accounting Curriculum”, Journal of Emerging Technologies in Accounting, 17 (1), pp. 107-117. 
Karabınar, Selahattin - Yılmaz, Erdal (2012), "Xbrl (Genişletilebilir İşletme Raporlama Dili) Ve Geleneksel Finansal Raporlama Sistemlerindeki Sorunların Çözümüne Katkıları”, Muhasebe ve Vergi Uygulamaları Dergisi, Cilt 5-2, ss. 1-24.

Karataş Arac1, Özlem Nilüfer - Bekçi, İsmail (2017), "Bulanık AHP Yöntemi İle Finansal Marka Değerleme Modellerinin Tespiti: Bankacılık Sektöründe Bir Uygulama”, Muhasebe ve Finansman Dergisi (75), ss. 31-54.

Kılınç, Yavuz (2020), "Blockchain Teknolojisi: Muhasebe Ve Denetim Mesleği Açısından Bir İnceleme”, Muhasebe ve Vergi Uygulamaları Dergisi, 13 (3), ss. 989-1011.

Koca, Gözde -Yıldırım, Seda (2020), "Bulanık Çok Kriterli Karar Verme Çalışmalarına Yönelik Bibliyometrik Analiz: 2005-2019”, Bilecik Şeyh Edebali Üniversitesi Sosyal Bilimler Dergisi, 5 (2), s s.257-272.

Kokina, Julia - Mancha,Ruben - Pachamanova, Dessislava (2017), “Blockchain: Emergent Industry Adoption and Implications for Accounting”, Journal of Emerging Technologies in Accounting, 14 (2), pp. 91-100.

Kütük, Yasin - Zor, Ümmügülsüm (2020), "Muhasebe Alanında Geliştirilen Uzman Sistemler”, Muhasebe ve Denetime Bakış, 61, ss.193-208.

Lombardi, Danielle - Dull, B. Richard (2016), “The Development of AudEx: An Audit Data Assessment System”, Journal of Emerging Technologies in Accounting, 13 (1), pp. 37-52.

Mckee, Thomas, E. (2009), “A Meta-Learning Approach to Predicting Financial Statement Fraud”, Journal of Emerging Technologies in Accounting, 6 (1), pp. 5-26.

Nigrini, Mark, J.- Johnson, Arlo (2008), "Using Key Performance Indicators and Risk Measures in Continuous Monitoring”, Journal of Emerging Technologies in Accounting, 5 (1), pp. 65-80.

O'brien, Ann, D. - Stone, Dan, (2020), "Yes, You Can Import, Analyze, and Create Dashboards and Storyboards in Tableau! The GBI Case", Journal of Emerging Technologies in Accounting, 17 (1), pp. 21-31.

O'leary, Daniel Edmund (2009), "The Ten Most-Cited Papers in Journal of Emerging Technologies in Accounting: The First Five Years”, Journal of Emerging Technologies in Accounting, 6(1), pp.1.

O'leary, Daniel Edmund (2010), “On the Number of ISI Citations to JETA, JIS, IJAIS, and ISAFM”, Journal of Emerging Technologies in Accounting, 7(1), pp. 89.

O'leary, Daniel, Edmund (2011), "The ten most-cited papers in Journal of Emerging Technologies in Accounting: 2009 versus 2011”, Journal of Emerging Technologies in Accounting, 8 (1), pp.1.

Onay, Ahmet (2020), "Büyük Veri Çağında İç Denetimin Dönüşümü” . Muhasebe Bilim Dünyası Dergisi, 22 (1), ss. 127-163.

Özkul, Fatma- Baş, Ece (2020), "Dijital Çağda Muhasebenin Dönüşümü: "Blockchain” Teknolojisinde Muhasebe ve Mali Kontroller”, Muhasebe Bilim Dünyası Dergisi, 22 (2) , ss. 218-236 .

Palmer, Richard, J. - Gupta, Mahendra, R. (2012), “Technology-Driven Convergence of Business Processes İn The Acquisition Cycle: Implications For Accountants And Educators” Journal of Emerging Technologies in Accounting, 8 (1), pp. 65-87.

Pinsker, Robert E. - Felden, Carsten (2015), "Professional Role and Normative Pressure: The Case of Voluntary XBRL Adoption in Germany”, Journal of Emerging Technologies in Accounting, 13 (1), pp. 95-118. 
Poroy Arsoy, Aylin - Ertan, Yasemin - Bora Kılınçarslan, Tuba (2018), “Genişletilebilir İşletme Raporlama Dili'nin (XBRL) Finansal Raporlama Gelişimine Katkısı ve TMS Taksonomisi Uygulaması”, Muhasebe ve Finansman Dergisi, Say1: 79, ss. 1-12.

Ragothaman, Srinivasan - Lavin, Angeline (2008), "Restatements Due to Improper Revenue Recognition: A Neural Networks Perspective”, Journal of Emerging Technologies in Accounting, 5 (1), pp. 129-142.

Rezaee, Zabihollah - Dorestani, Alireza - Aliabadi, Sara (2017), “Application of Time Series Analyses in Big Data: Practical, Research, and Education Implications”, Journal of Emerging Technologies in Accounting, 15 (1), pp. 183-197.

Rozario, Andrea - Thomas, Chanta (2019), "Reengineering the Audit with Blockchain and Smart Contracts”, Journal of Emerging Technologies in Accounting, 16 (1), pp. 2135.

Sağnak, Muhittin - Kazancoglu, Yiğit (2019), “IntegraFuzzy Analytic Network Process And 0-1 Goal Programming Technique For Enterprise Resource Planning (ERP) Software Selection”, Ege Academic Review, 19 (1), pp. 75-88.

Santos, Carlos - Sousa, Pedro - Ferreira, Carla; Tribolet, José (2008), “Conceptual Model for Continuous Organizational Auditing with Real Time Analysis and Modern Control Theory”, Journal of Emerging Technologies in Accounting, 5 (1), pp. 37-63.

Shawver, Tara, J. (2005), "Merger Premium Predictions Using a Neural Network Approach”, Journal of Emerging Technologies in Accounting, 2 (1), pp. 61-72.

Shirata, Cindy, Yoshiko - Takeuchi, Hironori - Ogino, Shiho - Watanabe, Hideo (2011), "Extracting key phrases as predictors of corporate bankruptcy: Empirical analysis of annual reports by text mining”, journal of Emerging Technologies in Accounting, 8 (1), pp. 31-44.

Shirata, Cindy, Yoshiko - Sakagami, Manabu (2008), "An Analysis of the "Going Concern Assumption”: Text Mining from Japanese Financial Reports”, Journal of Emerging Technologies in Accounting, 5 (1), pp. 1-16.

Sledgranowsk1, Deb - Gomaa, Mohammed - Tan, Christine (2017). “ Toward Integration of Big Data, Technology and Information Systems Comptencies Into The Accounting Curriculum”, Journal of Accounting Education, 38 (2017), pp. 81-93.

Smedley, Georgia A - Sutton, Steve, G. (2004), "Explanation Provision in Knowledge-Based Systems: A Theory-Driven Approach for Knowledge Transfer Designs”, Journal of Emerging Technologies in Accounting, 1 (1), PP. 41-61.

Söylemez, Yakup - Türkmen, Yılmaz, Sibel (2017), "Yapay Sinir Ağları Modeli İle Finansal Başarısızlık Tahmini”, Finans Ekonomi ve Sosyal Araştırmalar Dergisi, 2 (4), ss. 270284 .

Şener, İlge - Erman, Halil - Uzuner, Candan (2020), “Big Data of Big Companies: A Content Analysis For How ISO-500 Listed Firms Use Big-Data”, Enstitüsü Dergisi, 19. Uluslararası İşletmecilik Kongresi Özel Sayısı, ss. 130-145.

Tapis, Gregory - Priya, Kanu (2019), "Developing and Assessing Data Analytics Courses: A Continuous Proposal for Responding to AACSB Standard A5”, Journal of Emerging Technologies in Accounting, 17 (1), pp. 133-141.

Taş, Oktay - Mert, Haluk (2019), “Denetimde Yapay Zeka Uygulaması”, PressAcademia Procedia, 9 (1), ss. 65-68.

Teeter, Ryan - Alles, Michael - Vasarhelyi, Miklos A. (2010), “The Remote Audit”, Journal of Emerging Technologies in Accounting, 7 (1), 73-88. 
Terzi, Serkan - Şen, Kıymet, İlker (2012), "Finansal Tablo Hilelerinin Veri Madenciliği Yardımıyla Tespit Edilmesi: Üretim Sektöründe Bir Araştırma”, Muhasebe ve Vergi Uygulamaları Dergisi, 5 (2), ss. 25-40.

Uçoğlu, Derya (2020), "Yapay Zeka Teknolojisinin Muhasebe Mesleğine Ve Eğitimine Etkileri”, PressAcademia Procedia (PAP), V.11, ss. 16-21.

Uzun, Hülya (2020), "İşletmelerin Blok Zinciri (Blockchain) Uygulamalarında Ticari Birliklerin Rolü”, Bilecik Şeyh Edebali Üniversitesi Sosyal Bilimler Dergisi, 5 (1), ss. 88-109.

Vasarhelyi, Miklos, A - Alles, Michael - Kogan, Alexander (2004), "Principles of Analytic Monitoring For Continuous Assurance" Journal of Emerging Technologies in Accounting, 1 (1), pp. 1-21.

Yılmaz, Züleyha (2020), "Muhasebe Denetiminde Dijital Dönüşüm: Denetim Yazılımları”, Muhasebe ve Vergi Uygulamaları Dergisi, 13 (2), ss. 281-308.

Walley, Paul - Blenkinsop, S. - Duberley, Joanne (1994), "The Adoption and Non--Adoption of Modern Cost Accounting Practices: A Study of 20 Manufacturing Firms". International Journal of Production Economics. Vol. 36, pp. 19-27.

Weirich, Thomas R. - Tschakert, Norbert - Kozlowski, Stephen (2018), "Teaching Data Analytics Skills in Auditing Classes Using Tableau”, Journal of Emerging Technologies in Accounting, 15 (2), pp. 137-150.

Zhang, Chanyuan, Abigail (2019), “Intelligent Process Automation in Audit”, Journal of Emerging Technologies in Accounting, 16 (2), pp. 69-88. 